\title{
Entrepreneurship Education: Experiences in Selected Countries
}

\author{
Rosni Bakar ${ }^{1}$, Md Aminul Islam ${ }^{1} \&$ Jocelyne Lee ${ }^{1}$ \\ ${ }^{1}$ School of Business Innovation and Technopreneurship, Universiti Malaysia Perlis, Malaysia \\ Correspondence: Rosni Bakar, School of Business Innovation and Technopreneurship, Universiti Malaysia Perlis, \\ Malaysia. E-mail: rosnibakar@gmail.com
}

Received: May 12, 2014 Accepted: September 17, 2014 Online Published: December 30, 2014

doi:10.5539/ies.v8n1p88

URL: http://dx.doi.org/10.5539/ies.v8n1p88

\begin{abstract}
Entrepreneurship and education play a role in enhancing the country's economic state. Entrepreneurship helps the economy by providing job opportunities. The lack of job opportunities has caused unemployment rates to increase tremendously throughout the years making the development rate of a country slow down. One way for the economy to improve is by providing jobs for the unemployed. With technology improving day by day, the need for human labor decreases over time, this is where entrepreneurship comes in. The entrepreneur taking on the challenge of unemployment and provides an occupation for him and for others by being innovative is the act of entrepreneurship. Education is used to inspire entrepreneurship among young graduates in order for them to be able to produce job opportunities for themselves and their peers. Education is also seen as a method to eradicate poverty. Hand in hand, entrepreneurship and education plays a vital role and has been an interest of researchers. Entrepreneurship education is used to educate people with the skills and knowledge needed to be able to seize the opportunity presented. This paper discusses entrepreneurship and economic growth followed by entrepreneurship education along with the efforts and obstacles faced by Europe, China, Malaysia and Nigeria in enhancing entrepreneurship education. The paper intends to provide an understanding on entrepreneurship and its role in economic growth and entrepreneurship education.
\end{abstract}

Keywords: entrepreneurship, entrepreneurship education, economic growth

\section{Introduction}

In an attempt to develop a nation, the necessity for education is not to be undervalued. The progress of the education sector is vital to the development of the economic state of a country (Nkang, 2013). Education is the principal influence when concerning the growth and development of the country's economy (Adamu, 2008). In the current economy, education is not just to accomplish its most basic intention of producing and transferring new knowledge but also to improve the economy state of the country. Education is an opportunity that allows individuals to be inspired and given a chance to escape poverty by being provided with the necessary skills and knowledge needed (Aliu, 2007). Education is established as a method to eliminate poverty and entrepreneurship is seen as a substance to develop the economy.

In today's knowledge-based economy requires education institutions to provide knowledge and also to instill entrepreneurial intentions among university students and young graduates. With the emergence of the SME economy, there will be a necessity to provide students with the ability to identify opportunities and the knowledge and skills required to manage the opportunities (Hynes, 1996). It is an act of grooming the potential entrepreneurs.

Noting that entrepreneurship education is vital to the country's economy, one question that is to be pondered about is the length entrepreneurship education being able to contribute towards the economy. Entrepreneurship education has been the center of attention among researchers (Mason, 2011) and several countries has shown their interest in building the entrepreneurial spirit among its people through entrepreneurial activities and programs. Therefore, this study will look at the role of entrepreneurship education in promoting growth. This paper will be separated into four sections. The first section is the introduction. The second section of the paper gives a review on entrepreneurship education whereas the third discusses about entrepreneurship and the fourth part is a brief summation of the relationship between entrepreneurship education and growth.

\section{Entrepreneurship and Economic Growth}

Entrepreneurship is often associated with economic development, where by economic development suggests 
activities that facilitates in the improvement of the country and society's standard of living. Fauziah, Rohaizat and Siti (2004) and Arokiasamy (2012) have concluded that entrepreneurship has a vital role in the economy and also the growth of the economy. It is suggested that entrepreneurship activity contributes to economic development either on the national and regional level, using GDP as an indicator of economic growth or development (Ahmad \& Xavier, 2011). Entrepreneurship is a mean to beat youth unemployment. The Hufftington Post in its article mentions that many unemployed youths are venturing into business as a method of tackling the feeble job market in Europe, Middle East and North America. Forbes also suggests that getting a job for a young graduate might not be the right way. With the proper guide and investment in entrepreneurship, these young graduates will be able to create their own jobs and also create jobs for others. Along with the guidance and encouragement, the entrepreneurs will fabricate new trends that will be able to improve the community and develop economies.

Activities assumed by small medium enterprises (SMEs) are often paralleled with entrepreneurship activities and the activities of these SMEs carry heavy weights on the development of the economy of Malaysia (Ramayah, Ahmad, \& Ho, 2012).

The role of entrepreneurship in the improvement of a country's economy has been largely discussed (Carree \& Thurik, 2010). Wennekers and Thurik (1999) find that entrepreneurship does play an important role in a country's economy. Porter (1990, cited by Carree \& Thurik, 2010) states that entrepreneurship is "at the heart of national advantage". The powerful demand for entrepreneurship is prompted by globalization and the improvement of economic performance. One country that has benefited widely from its entrepreneurial activities is China. The Global Entrepreneurship Monitor (GEM) report mentions that China is favorably categorized as a country with relatively high entrepreneurial intentions, and is also a country that is in an efficiency driven economy, similar to Malaysia.

Using Malaysia as an example, entrepreneurship in Malaysia is important and can be seen when SME Corp in 2010 reported that $99.2 \%$ of business establishments in Malaysia are SMEs, employing 5.6 million of the workforce and contributing roughly $32 \%$ of the country's gross domestic product. The Malaysian government is organizing instruments and policies to assist and support entrepreneurs. Support such as funding, physical infrastructure and business advisory services are employed (Ariff \& Syarisa, 2003). Another method of support comes in the form of The National SME Development Council, which was first set up in august 2004 and carries the task of formulating and implementing the direction and strategies concerning the development of SMEs (Normah, 2007). The Malaysian Government has also launched the Entrepreneur Development Fund, the Bumiputera Entrepreneurship Project Fund, the Asia Japan Development Fund, the Credit Guaranteed Corporation Scheme and the Franchise Development Programme (Ramayah \& Zainon, 2005). To what extent entrepreneurship education helps the economy at this moment cannot be measured as there is no particular way to assess the choice of career of the society and therefore the economic and societal impact of entrepreneurship education cannot be quantified (Weber, Graevenitz, \& Harhoff, 2009). However, the Global Entrepreneurship Monitor is able to measure the level of entrepreneurial activities in a country by using their own model, the Total Early-Stage Entrepreneurial Activity (TEA) rate and GEM has also identified certain models that show how the entrepreneurial process affect the country's economy. Aside from GEM, Wennekers and Thurik (2010) also mentions a framework, produced in 1999 depicting how entrepreneurial activities affect the country's economy. 


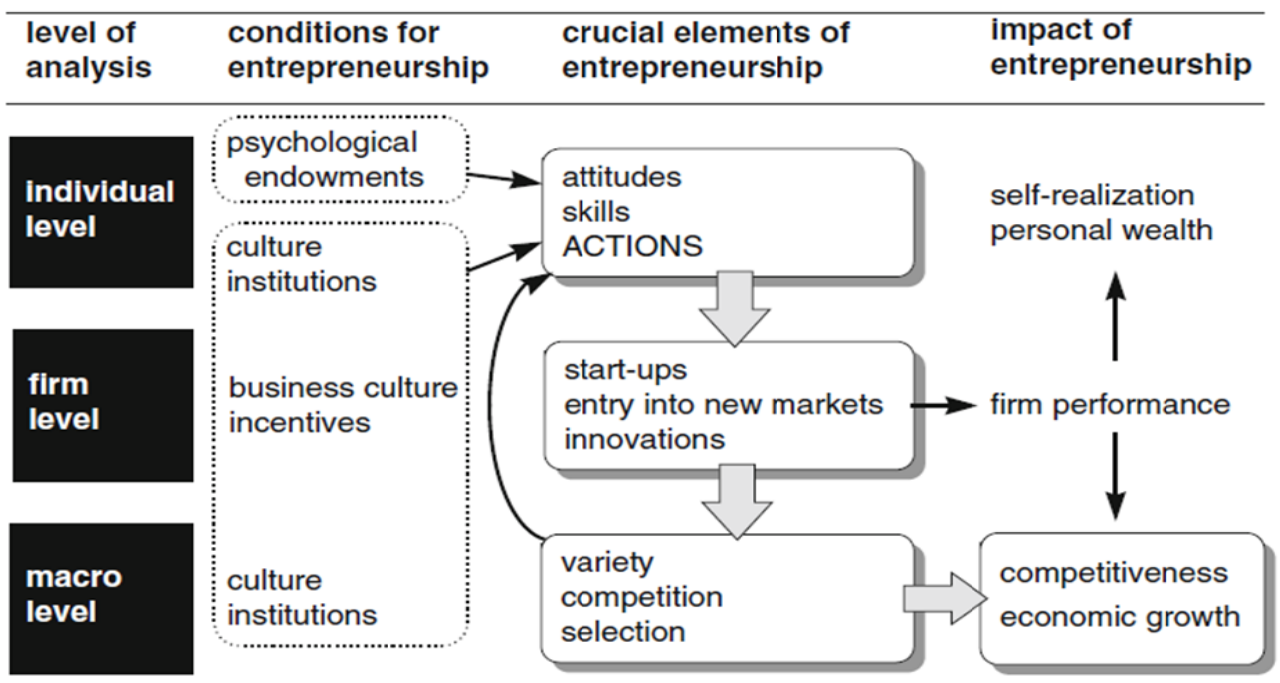

Figure 1. Wennekers and Thurik's framework linking entrepreneurship to economic growth

The model depicted by Wennekers and Thurik characterizes three separate levels, the individual level, the firm level and the macro level. The individual level is where entrepreneurship originates from, where the entrepreneur carries out an activity that is known as entrepreneurship. However, the entrepreneur cannot undertake any entrepreneurial activities on his own without being affected by the background of which he is prone to. This situation explains that entrepreneurial motives are influenced by culture and institutional factors, namely entrepreneurship education, and the economic conditions.

Despite entrepreneurship being instigated at the individual level, comprehension of the idea is only achieved at the firm level. Startups are mediums that help in realizing the individual entrepreneurial qualities into actions. At the macro level, it involves the industry and the national economy. At this level, the entrepreneurial activities comprises of competing experiments, new ideas and initiatives. The competition is ensued by the offering of several choices in the market. Therefore, entrepreneurial activities develop and alter the potential of the country's economy by encouraging higher productivity and the development of new niches and the industry.

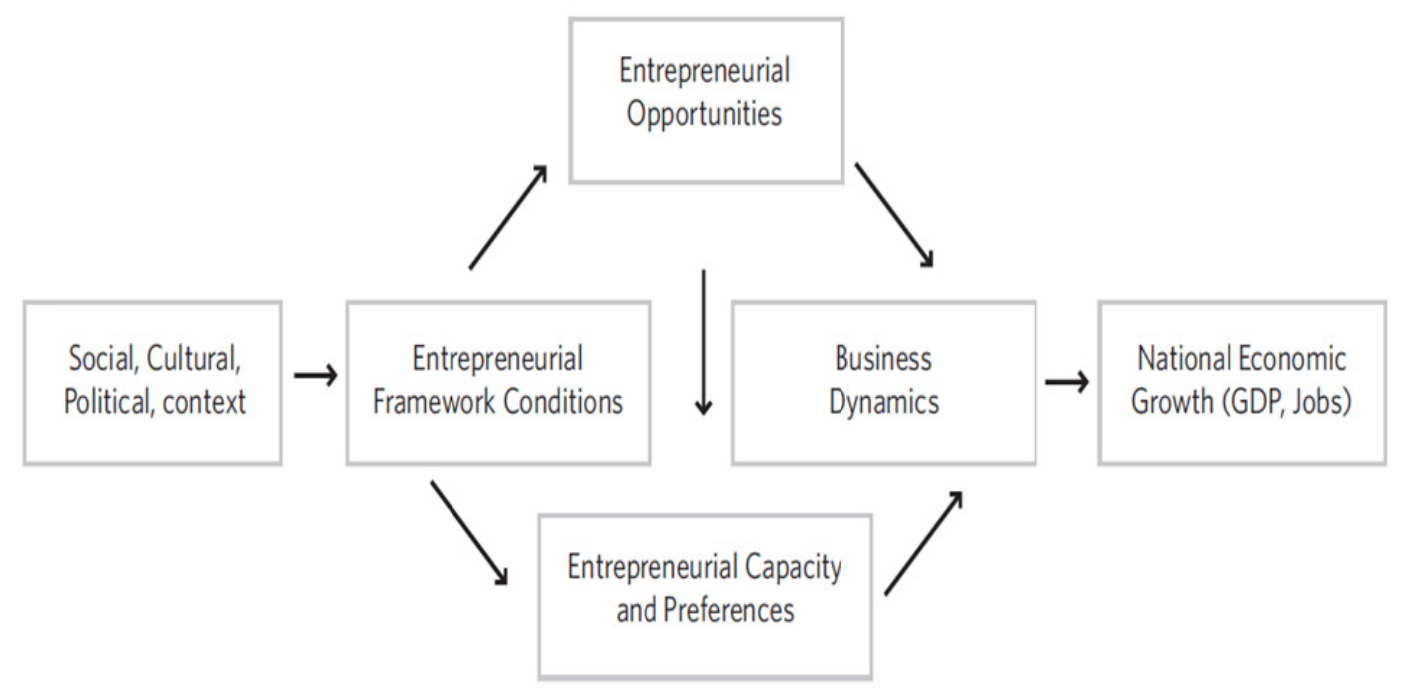

Figure 2. GEM model (Source: GEM 2013 Global Report) 
The GEM model, adapted from Reynolds, Hay and Camp (1999) finds a strong relationship between entrepreneurship and economic growth. This model has factors that are usually left out in the conventional framework, which is the acknowledgment that entrepreneurial activity is formed with a distinct set of factor, known as the Entrepreneurial Framework Conditions by GEM. The framework conditions play a vital role because it influences the existence of opportunity and capacity for entrepreneurial activities that will further on affect the county's economy (GEM, 2013).

Table 1. GEM's entrepreneurial framework conditions

1 Entrepreneurial Finance. The availability of financial resources-equity and debt-for small and medium enterprises (SMEs) (including grants and subsidies).

Government Policy. The extent to which public policies give support to entrepreneurship. This EFC has two components:

2 2a. Entrepreneurship as a relevant economic issue and

$2 \mathrm{~b}$. Taxes or regulations are either size-neutral or encourage new and SMEs.

3 Government Entrepreneurship Programs. The presence and quality of programs directly assisting SMEs at all levels of government (national, regional, municipal).

Entrepreneurship Education. The extent to which training in creating or managing SMEs is incorporated within the education and training system at all levels. This EFC has two components:

4 4a. Entrepreneurship Education at basic school (primary and secondary)m and

4b. Entrepreneurship Education at post-secondary levels (higher education such as vocational, college, business schools, etc.).

5 R\&D Transfer. The extent to which national research and development will lead to new commercial opportunities and is available to SMEs.

6 Commercial and Legal Infrastructure. The presence of property rights, commercial, accounting and other legal and assessment services and institutions that support or promote SMEs.

Entry Regulation. Contains two components:

7 7a. Market Dynamics: the level of change in markets from year to year, and

7b. Market Openness: the extent to which new firms are free to enter existing markets.

8 Physical Infrastructure. Ease of access to physical resources-communication, utilities, transportation, land or space - at a price that does not discriminate against SMEs.

9 Cultural and Social Norms. The extent to which social and cultural norms encourage or allow actions leading to new business methods or activities that can potentially increase personal wealth and income.

Source: GEM Global Report 2013.

Entrepreneurship does indeed play a vital role in a country's economy (GEM 2013; Wennekers \& Thurik, 1999). Entrepreneurship education in GEM's Entrepreneurial Framework Condition shows the significance of entrepreneurship education in fostering entrepreneurial activity among the individuals. Entrepreneurial activities can be inspired using entrepreneurship education. Many countries in the world are looking towards using entrepreneurship education as a medium to instill the entrepreneurial drive among individuals. A country like Nigeria is looking towards entrepreneurship education as a method to ease poverty. Entrepreneurship education is a great help in facing the current poverty issue in Nigeria (Ediagbonya, 2013). Entrepreneurship education helps in reducing poverty by equipping the people with skills to be entrepreneurs, reducing the number of people who are unemployed by giving them the opportunity to be self-employed (Ediagbonya, 2013).

Entrepreneurship itself is more than a simple creation of a business. It is a unified concept that allows entrepreneurs to develop their business in an innovative manner that consequently has transformed the way business is conducted in every country. (Kuratko, 2003). The emergence of entrepreneurial activity has helped several economies recover from a downfall. Since 1980 in the U.S, more than 34 million new jobs were created despite many Fortune 500 companies losing more than 5 million jobs (Kuratko, 2003). U.S achieved its peak economic performance in the 90's through the nurturing and development of entrepreneurial activity (Kuratko, 
2003). Companies who take on the entrepreneurial outlook have made two crucial inputs to the U.S economy. First of all, entrepreneurs play a vital role in the innovation that lead to change in technology and also growth in productivity as entrepreneurs and their firms are based on change and competition and they have the ability to change the market. Entrepreneurial activities are about the outlook of the future and not the past (Kuratko \& Hodgetts, 2004).

Secondly, being a vital device for millions to enter the economic and social livelihood of the American society, entrepreneurial firms allow millions of people to be part of the American Dream which is economic growth, equal opportunities, and upward mobility (Kuratko, 2003). Entrepreneurship plays the critical and essential role of combining business activities together to create better and innovative ones.

\section{Entrepreneurship Education}

Unlike traditional management studies, entrepreneurship education requires a different teaching direction. Entrepreneurial aptitude can be developed through education as the individuals' personality and capability can be distinctively cultivated based on the environment of his or her education and willpower (Lee, Chang, \& Lim, 2005). The trait of entrepreneurship is thought to be born, however, previous studies has shown that regardless of the assumption most people have regarding entrepreneurship being born, there are ways to enhance entrepreneurship qualities in an individual (Cheng \& Chan 2004). This then indicates how indispensable entrepreneurship education is.

Entrepreneurship education has the possibility to stimulate consciousness towards self-employment as a career option; there are implications that the consciousness towards self-employment inspires young people to equip themselves with the knowledge, skills and experience needed to acquire a successful business (Flemming, 1996 as cited in Ahmad, 2013). It is referred as a legitimate programme that is done to prepare students with the required skills and knowledge to be able to identify opportunities, understand a customer's perception, generate new ideas and developing business plans, as well as understanding and evaluating environmental, institutional and political issues (Cheng, Chan, \& Mahmood, 2009). Students who take part in entrepreneurship programmes tend to have a higher possibility to start their own business (Matlay, 2008).

The basic goal of entrepreneurship education is to foster the entrepreneurial culture among students. Alain (2009) and Akudolu (2010) see entrepreneurship education as the nurturing of entrepreneurial mindsets, attitudes and skills that allows the individual to take charge of the economic situation and to identify opportunities. Several researchers like Oborah (2006), Garavan and O'Cinneide (1994, as cited in Chigbuson, 2011) have summarized the objectives of entrepreneurship education. Some outlined objectives that are supporting the statement that entrepreneurship education improves the economic state of the country are:

Stimulating industrial and economic growth

Nurturing entrepreneurial mindset, skills and behavior.

Providing SMEs the opportunities to employ graduates who have received training and have the skills and knowledge needed for entrepreneurial companies.

Allowing students to have enough knowledge to be able to identify opportunities and create new business and provide more job opportunities for the society.

Increasing the knowledge and perception concerning the process of initiating and managing a new venture.

The European Commission in 2012 mentions that entrepreneurship education plays a role in influencing society and the economy. Among the finest methods in assisting economic growth and create job opportunities is through entrepreneurship education. With new businesses as the largest foundation for new jobs in Europe, education aids in creating businesses (European Commission 2013).

Consistent with the realization that education and entrepreneurship is the drive for the economy, researchers, educators as well as the public and private bodies are focusing on entrepreneurship education (Mason, 2011). Many countries are being active in the application of entrepreneurship education in various higher education institutions as well (Fayolle \& Klandt, 2006; Casson, 2005).

There have been suggestions from educators stating that introducing entrepreneurship into school curriculums can serve the objective of refining student performance outcomes and to educate the concept of business ownership as an option of employment to students (Stem, Stone, Hopkins, \& Crain, 1994 as cited in Ahmad, 2013). Entrepreneurship education will be able to give students a clear perception towards business, comprising of its principle, its composition and the association of business along with sectors like economy and society (Ahmad, 2013). 
Blenker, Dreisler, and Kjeldsen (2006) mentions that to some extent, entrepreneurship can be learned thought education and teaching, however it should assume a special kind didactic and instruction that emphasizes on the development of academic and individual proficiency. Entrepreneurship education can be seen as a way and mean to assist student to excel when setting up a new business venture or small medium enterprise (SME).

Various approaches towards entrepreneurship education have been taken. Some of which are on the effectiveness of entrepreneurship education (Cheng et al., 2009), whether or not entrepreneurship can be taught (Dana, 2001; Henry, Hill, \& Leitch, 2005), the impact academic career training has on the ability to innovate and recognize opportunities.

Presently, the general manner of delivery in teaching entrepreneurship is through lectures. On the other hand, more interactive methods like guest speakers ad interactions with successful entrepreneurs are less utilized (Cheng et al., 2009). Donald (2005) mentions that there is no general understanding on how entrepreneurship education is apprehended in higher education institutions and there is insufficient experience in implementing entrepreneurship within education institutions. Universities play an important role in promoting entrepreneurship and encourage students' inclination towards entrepreneurship. This statement is supported by Ooi (2008), who in his research found that there is a significant relationship on the roles of the university in promoting entrepreneurship. He found that there is a positive relationship between entrepreneurship and the students' inclination towards entrepreneurship. Arokiasamy (2012) also mentions that entrepreneurial movement is prevented by minimal education and exposure.

Mastura and Abdul-Rashid (2008) also concluded that a students' inclination towards entrepreneurship is affected by education. Ramayah, Ahmad, and Ho (2012), also found that entrepreneurship education plays an important role in entrepreneur intentions and entrepreneur careers. This is also confirmed by studies from other researchers namely Matlay (2008); Ramayah and Zainon (2005) and Souitaris, Stefania, and Andreas (2007) and more. Arokiasamy (2012) also states that "A low level of education and exposure could prevent motivated entrepreneurial movement in their surroundings". Entrepreneurship education is a method of giving students information regarding their career options and providing them with the opportunity to gather knowledge and to assess for themselves, which career is suitable for them (Weber, Graevenitz, \& Harhoff, 2009).

There are several ways in offering entrepreneurship education. The methods used are to be based on the objectives of the lessons. Hytti and O'Gorman (2004) suggest that there are several ways to present entrepreneurship education. Should the objective of the lessons are to provide individuals with entrepreneurial skills, the best way will be to provide education and training that allows the individual to be directly involved in the process.

With a lot of attention paid to the introduction and the employment of entrepreneurship educations, the efforts put in to encouraging entrepreneurship education does not come without issues. There are several disputes on hand concerning entrepreneurship and various studies have been conducted to obtain a clear understanding of the issues which are best answered using interrogatives 'what', 'where', how', 'why', 'when' and 'with which or whom' of entrepreneurship (Mason, 2011). 'What' is what to teach, such as the content of the lessons, 'where' is to identify which level is best to introduce entrepreneurship education, 'how' is the procedure and curriculum used. These topics are rather popular choices for research topics and there are not much conclusive findings on the procedures and curriculums used to project entrepreneurship education to students and individuals (Mason, 2011).

\subsection{Malaysia}

Malaysia was introduced to entrepreneurship education as early as the 1980 s by institutions of higher learning but this subject was not given attention for a period of time (Othman, Hashim, \& Wahid, 2012). Malaysia started paying attention to entrepreneurship education in the mid-1990s (Cheng, Chan, \& Mahmood, 2009) as a result of the new economy surfacing whereby knowledge is the largest resource in a majority of economic activities. Education on entrepreneurship prepares individuals with innovative business skills to obtain opportunities as well as to set the pace of the new economy through shaping new entrepreneurial activity (Mahmood \& Cheng, 2005).

The Ministry of Higher Education (MOHE) has also launched the Entrepreneurship Development Policy for Institutes of Higher Education with the goal of producing quality human capital that is graduates who own the traits and significance of entrepreneurship (Modul Pembangunan Kemahiran Insaniah (Soft Skills) Untuk Institusi Pengajian Tinggi Malaysia, 2006). The Ministry of Higher Educations' move to instil the entrepreneurship development policy shows that the ministry realises the vital roles education plays in developing entrepreneurial skills. Ibrahim and Soufani, (2002) also discuss that schools and education systems 
play a vital role in recognizing and molding entrepreneurial traits. Today's education system in Malaysia sees a majority of the public universities offering entrepreneurship courses as a core subject (Othman \& Ismail, 2012).

Entrepreneurship education is employed in High Education Institutions through educating and learning activities (Mohd-Fauzi, Yahaya, Tih, \& Poon, 2007). The education goals of the higher education institutions (HEI) which are designed to assist the economic growth of the country, by developing human potential through training in diverse areas and to produce a trained group that will function as the nation's human capital, are met with the introduction of entrepreneurship in the education system (Norfadhilah \& Norasmah, 2012).

There are several researchers who have undertaken a series of research regarding entrepreneurship education as well as certain aspects that influence it in Malaysia. Cheng and Chan (2004) investigate the development of entrepreneurship education. Their research concentrates on the students' knowledge concerning entrepreneurship, the aspects that are affecting the student's decisions to be entrepreneurs as well as the drive to own a business after completing their education.

Nawai and Shariff (2011) mentions that out of the total Small and Medium Enterprises (SMEs) in Malaysia, $80 \%$ of that amount accounts for micro-enterprises and the micro-enterprise totals to $78.7 \%$ of all the business establishments in Malaysia. Universities in Malaysia play an important role to nurture the entrepreneurial spirit among students to improve the micro-enterprises in to larger scale firms that will help and contribute to the economy.

\subsection{China}

Several observations towards the development of entrepreneurship education in China have been carried out. It is noted that entrepreneurship education is a new concept that has received instant expenditure on its management course. Majorities of the course offered are short-term, programmes and are tailor-made vocational education and training (Mason, 2011). The end of 1990s marks the occurrence of entrepreneurship programmes to be offered to the undergraduates and post-graduates ( $\mathrm{Li}$, Zhang, \& Matlay, 2003). During this phase when entrepreneurship programmes start making its mark in China, three events that are considered to be elevated among the Chinese community. The first is the student business plan competition, the second is the establishing of the National Entrepreneurship Research Centre, a Graduate Venture Park and four venture capital funds by Tsinghua University and the third event is the introduction of new regulations whereby in the engagement towards venturing into a new business, students are allowed to postpone their studies for up to three years $(\mathrm{Li}$, Zhang, \& Matlay, 2003).

Being sensitive to the changes in the socio-economic and political environment, the advancing progress of rural areas and enterprises, the need of management programs to guarantee better administration of firms, the increasing understanding that entrepreneurship education is an essential part of proficiency and ability among students are the key drivers for the development of entrepreneurship education. The extraordinary growth in economic has liberated the entrepreneurial essence in China (Mason, 2011). However, there are also certain barriers for entrepreneurship education to develop. Barriers such as the environmental barrier to start and run business, lack of funding and resources, political uncertainty and the diminishing consistency of policies prevent the growth of entrepreneurship education in China (Mason, 2011).

\subsection{Europe}

Entrepreneurship education is something that has been long supported by the European Commission an approach to achieve the Europe 2020 strategy. It is vital as it helps form the mentality of future generations as well as equipping them with the skills and knowledge needed that is crucial when nurturing an entrepreneurial culture (European Commission 2013). The European Commission has come up with a strategic plan to enforce entrepreneurship education ensuring that it is thought in every school in Europe. Entrepreneurship education is thought as it plays a major role in developing the younger generations mind and also presents them with the skills and knowledge necessary for entrepreneurs.

The growth of entrepreneurship education in Europe has been consistent and the growth is expected to continue (Wilson, 2008). However, there are parts in entrepreneurship education that needs to be improved in Europe. Wilson (2008) has identified five parts which are curriculum development, funding for entrepreneurship, research collaborations, increase in number of teachers for entrepreneurship education and extensions from technical and scientific institutions.

Entrepreneurship education in Europe is offered in business schools. It is to be expanded throughout the campus especially to the departments that specialized on science and technology as it is the place where innovation starts (Wilson, 2008). Currently, entrepreneurship education is making its path to be widely known and accepted by 
most individuals in Europe. The existing situation regarding entrepreneurship education sees that there are rather limited educators that can help nurture and deliver the entrepreneurship education course. Despite the increasing number of demand from students concerning entrepreneurship programmes, there is "a lack of critical mass of entrepreneurship professors at many universities across Europe" (Wilson, 2008).

It is an important step to be able to provide the students with the right people to educate them about entrepreneurship. With the growing number of students interested in entrepreneurship education, an adequate amount of educators should be provided for the students. Educators in Europe are not limited to professors but it is suggested that entrepreneurs themselves be part of the educating force as they are able to provide a first person view on entrepreneurship and work as a role model for the students.

\subsection{Nigeria}

Nigeria started its development in entrepreneurship education 2006 (Yahya, 2011; Gabadeen \& Raimi, 2012), and it is embraced to assist and hasten the economic growth and development of the country.Entrepreneurship education is introduced as it is a practical method to overcome the epidemic setback the country is facing, unemployment (Akhuemonkhan \& Sofoluwe, 2013).

Regardless of the students' area of study, entrepreneurship education is now a compulsory course for all undergraduate students (Yahya, 2011). Universities and polytechnics in Nigeria hold the responsibility of transferring entrepreneurial knowledge to students. The roles of the universities, polytechnics and colleges is not only to educate students about entrepreneurship education but also to ensure that entrepreneurship education is well established in all higher education institutions and a curriculum for the course is formed.

The current development in entrepreneurship education in Nigeria is at a decreasing speed. This is occurring as entrepreneurship education is introduced at a late stage to Nigeria and is facing certain challenges. The present state of implementation is feeble (Akhuemonkhan, Raimi, \& Sofoluwe, 2013). There is also excessive stress on writing business plans in students which has caused a flaw in the method of teaching entrepreneurship education (Ifedili \& Ofoegbu, 2011). Entrepreneurship education is conveyed much well if it conducted through talks and implementations of business projects for the students to experience activities about entrepreneurship (Akhuemonkhan, Raimi, \& Sofoluwe, 2013).

The current obstacle that Nigeria is facing is funding. Being unable to obtain funding has cause the implementation of entrepreneurship education curricula to be affected in a damaging manner. Aside from the difficulty of obtaining funding, there is also the inaccurate perception from students thinking that entrepreneurship education is enforced by the government to multiply their workload (Ifedili \& Ofoegbu, 2011; Gabadeen \& Raimi, 2012) and this belief has caused students to be disheartened in venturing into entrepreneurship activities inside and outside the classroom (Ifedili \& Ofoegbu, 2011).

\section{Summary}

Entrepreneurship is now known as a factor that widely contributes to the country's economy. Education is also seen as being able to alleviate the economy of a country. Ijaiya (1998) states that education is a necessity to relieve Nigeria of poverty. Entrepreneurship and education are both important tools in improving a country's current economic state. It became apparent to most educators that entrepreneurship is something that can be taught; discrediting the idea that entrepreneurship is born and not made (Kuratko, 2003). Cho (1998, cited by Lee, Chang, \& Lim, 2005) states that entrepreneurial ability is not innate, for if it were a skill that is born, entrepreneurship education will lose its implications. In the U.S, entrepreneurship education is introduced in the early 1970 s and by 2005 , entrepreneurship education in the U.S. has been expanding constantly with more than 2,200 courses in 1,600 schools and the existence of management journals that are dedicated to the idea of entrepreneurship (Kuratko, 2003).

Entrepreneurship can be instilled into an individual with the correct method. Education on entrepreneurship influences the entrepreneurial intentions among individuals (Mastura \& Abdul-Rashid, 2008; Matlay, 2008; Ramayah \& Zainon, 2005; Souitaris et al., 2007) which will then help the country's economy with the creation of job opportunities when an individual decides to venture into owning a business.

On the regards to how entrepreneurship education affects the economy is seen on how it has steered individuals into venturing into entrepreneurship. Entrepreneurship education, at its core is to educate people about building skills in fields like negotiation, leadership, new product development, creative thinking and innovation, as well as awareness of entrepreneurship as a career option (McMullen \& Long, 1987; Vesper \& McMullen, 1988; Hill, 1988; Donckels, 1991 as cited by Kuratko, 2003). Entrepreneurship education enables an individual to see an obstacle as an opportunity and take the opportunity to create a new venture that will in return create 
opportunities for other individuals to have employment.

Entrepreneurship helps enhance the economy of a country. Before being able to enhance the economy, there must be the want and desire to venture into entrepreneurship. The best way to encourage people to venture into entrepreneurship is to educate them on the benefits and the potential they have in entrepreneurial activities. Entrepreneurship education does have an impact on the country's economy as it is the activity that is relied upon to inform and to nurture the entrepreneurial spirit among individuals. A proper session on education individuals about entrepreneurship will change how they see entrepreneurship and possibly make the individuals more inclined into venturing on their own, starting up new business and providing more job opportunities for the society.

\section{References}

Adamu, U. (2008). Motionless Points in Chaos: Education Reforms, Innovations and The Challenges for Tertiary Education in Nigeria. 1st National conference organized by Kano State Polytechnic. Retrieved from http://aadcice.hiroshima-u.ac.jp/e/publications/sosho4_1-08.pdf

Ahmad, S. Z. (2013). The need for inclusion of entrepreneruship Education in Malaysia lower and higher learning institutions. Education + Training, 55(2), 191-203. http://dx.doi.org/10.1108/00400911311304823

Ahmad, S., \& Xavier, R. (2012). Entrepreneurial environments and growth: evidence from Malaysia GEM data. Journal of Chinese Entrepreneurship, 4, 50-69. http://dx.doi.org/10.1108/17561391211200939

Akhuemonkhan, I. A., Raimi, L., \& Sofoluwe, A. O. (2013). Entrepreneurship Education and Employment Stimulation in Nigeria. Journal of Studies in Social Sciences, 3, 55-79. Retrieved from http://infinitypress.info/index.php/jsss/article/viewFile/66/77

Akudolu, L. (2010). A Curriculum Framework for Entrepreneruship Education in Nigeria. Unizik Orient Journal of Education, 1-16. Retrieved from http://scholar.google.com.my/scholar?q=A+Curriculum+Framework+ for + Entrepreneruship + Education + in + Nigeria\&btnG $=\& \mathrm{hl}=$ en\&as_sdt $=0 \% 2 \mathrm{C} 5$

Alain, F. (2009). Entrepreneurship Education in Europe: Trends and Challenges. OECD LEED programme: Universities, Innovations and Entrepreneruship Good Practice Workshop. Retrieved from http://www.oecd.org/regional/leed/43202553.pdf

Aliu, S. (2007). Entreprenuership Education: An Overview Teacher's Guide on Entrepreneurship Education for Polytechnic and Monotechnics in Nigeria. Retrieved from http://www.iiste.org/Journals/index.php/JEP/article/download/4072/4107

Amoros, J. E., \& Bosma, N. (2013). GEM 2013 Global Report. Retrieved from http://www.gemconsortium.org /docs/download/3106

Ariff, M., \& Syarisa, Y. A. (2003). Strengthening entrepreneurship in Malaysia. Retrieved from http://www.mansfieldfdn.org/backup/programs/program_pdfs/ent_malaysia.pdf

Arokiasamy, A. R. (2012). The Influence of Globalization in Promoting Entrepreneurship in Malaysia. South East European Journal of Economics \& Business. http://dx.doi.org/10.2478/v10033-012-0021-7

Berman, J., \& Sherriff, L. (2013, November 22). Global Youth Unemployment Crisis Spurs Young Entrepreneurs To Get Creative. Retrieved April 2, 2014, from http://www.huffingtonpost.com/2013/11/22/global-youthunemployment_n_4316068.html

Blenker, P., Dreisler, P., \& Kjeldsen, J. (2006). Entrepreneurship Education-the New Challenge Facing the Universities. Retrieved from http://www.hha.dk/man/cmsdocs/WP/2006/2006-02_ENG.pdf

Carree, M. A., \& Thurik, R. A. (2010). The Impact of Entrepreneurship on Economic. Handbook of Entrepreneurship Research, International Handbook Series on Entrepreneurship 5. http://dx.doi.org/10.1007/0-387-24519-7_17

Casson, M. (2005). Entrepreneurship and the Theory of the firm. Journal of Economic Behavior \& Organization, 327-348. http://dx.doi.org/10.1016/j.jebo.2004.05.007

Cheng, M. Y., Chan, W. S., \& Mahmood, A. (2009). The effectiveness of entrepreneurship education in Malaysia. Education + Training, 51(7), 555-566. http://dx.doi.org/10.1108/00400910910992754

Cheng, M., \& Chan, C. (2004). Entrepreneurship Education in Malaysia. Cyberjaya Multimedia. http://dx.doi.org/10.1504/IJESB.2012.050169

Chigbuson, A. (2011). Entrepreneurship Education and Training in Nigeria Tertiary Institution: Issues and 
Challenges. ABEN Book of Readings, 140-146. Retrieved from http://www.eajournals.org/wp-content/ uploads/Driving-Entrepreneurship-Education-in-Nigeria-Issues-and-Challenges.pdf

Dana, L. P. (2001). The Education and Training of Entrepreneurship in Asia. Education+Training, 43, 405-415. Retrieved from http://www.emeraldinsight.com/doi/abs/10.1108/EUM0000000006486

Ediagbonya, K. (2013). The Roles of Entrepreneurship Education in Ensuring Economic Empowerment and Development. Journal of Business Administration and Education, 35-46. Retrieved from http://www.infinitypress.info/index.php/jbae/article/viewFile/220/176

Entrepreneurship education key to sustainable economic upswing. (2012, October 1). Retrieved March 20, 2014, from http://ec.europa.eu/enterprise/magazine/articles/smes-entrepreneurship/article_11079_en.htm

Fauziah, S., Rohaizat, B., \& Siti, H. A. (2004). Interest in Entrepreneurship: An explarotary study on engineering and technical student in entrepreneurship education and choosing entrepreneur as a career. Retrieved from http://eprints.utm.my/2668/1/71790.pdf

Fayolle, A., \& Klandt, H. (2006). Issues and newness in the field of entrepreneurship education: New lenses for new practical and academic questions. In A. Fayolle, \& H. Klandt (Eds.), International Entrepreneurship Education Issues and Newness (pp. 1-20). Northampton: Edward Elgar. Retrieved from http://www.untag-smd.ac.id/files/Perpustakaan_Digital_1/ENTREPRENEURSHIP\%20International\%20En trepreneurship\%20Education.pdf

Gabadeen, W. O., \& Raimi, L. (2012). Management of Entrepreneurship Education in Nigerian Higher Institutions: Issues, Challenges and Way Forward. Abuja International Journal Of Education And Management Sciences, 1-26. Retrieved from http://scholar.google.com.my/scholar?q=related: KWVtF42gIwQJ:scholar.google.com/\&hl=en\&as_sdt=0,5

Henry, C., Hill, F., \& Leitch, C. (2005). The effectiveness of training for new business creation. International Small Business Journal, 22(3), 249-269. http://dx.doi.org/10.1177/0266242604042378

Hynes, B. (1996). Entrepreneurship education and training-introducing entrepreneurship into non-business $\begin{array}{lllll}\text { disciplines. Journal of European Industrial Training, 20(8), } & \text { 10-17. }\end{array}$ http://dx.doi.org/10.1108/03090599610128836

Hytti, U., \& O'Gorman, C. (2004). What is 'Enterprise Education'? An analysis of the objectives and methods of enterprise education programmes in four European countries. Education + Training, 46(1), 11-23. http://dx.doi.org/10.1108/00400910410518188

Ibrahim, A. B., \& Soufani, K. (2002). Entrepreneurship and Training in Canada: A Critical Assessment. Education + Training, 44(8/9), 421-430. http://dx.doi.org/10.1108/00400910210449268

Ifedili, C., \& Ofoegbu, F. (2011). Managing Entrepreneurship Education In Nigerian Universities. European Journal of Educational Studies. Retrieved from http://memberfiles.freewebs.com/56/91/55839156/ documents/MANAGING\%20ENTREPRENEURSHIP\%20EDUCATION\%20IN\%20NIGERIAN\%20UNI VERSITIES.pdf

Ijaiya, G. (1998). Alleviating Poverty in Nigeria: Investing in Education as a Necessary Recipe. Ilorin Journal of Education, 125-131. Retrieved from https://unilorin.edu.ng/journals/education/ije/sept1998/Alleviating\% 20Poverty\%20in\%20Nigeria.pdf

Kuratko, D. (2003). Entrepreneurship Education: Emerging trends and challenges for the 21st century. Coleman White Paper Series. Retrieved from http://www.unm.edu/ asalazar/Kauffman/Entrep_research/e_ed.pdf

Kuratko, D., \& Hodgetts, R. (2004). Entrepreneurship: Theory, Process, Pratice. Mason, OH: South-Western Publishers.

Lee, S. M., Chang, D., \& Lim, S.-B. (2005). Impact of Entrepreneurship Education:A Comparative Study of the U.S. and Korea. International Entrepreneurship and Management Journal, 1, 27-43. http://dx.doi.org/10.1007/s11365-005-6674-2

Li, J., Zhang, Y., \& Matlay, H. (2003). Entrepreneurship Education in China. Education + Training, 45(8/9), 495-505. http://dx.doi.org/10.1108/00400910310508883

Mason, C. (2011). Entrepreneruship Education and Research: Emerging Trends and Concerns. Journal of Global Entrepreneurship, 1. Retrieved from https://entrepreneurship.okstate.edu/files/The_Emergence_of_ Entrepreneurship_Education_Development_Trends_and_Challenges.pdf 
Mastura, J., \& Abdul-Rashid, A. (2008). Entrepreneurship Education in Developing Country. Exploration on its necessity in the construction program. Journal of Engineering, Design and Technology, 6(2), 178-189. Retrieved from http://www.emeraldinsight.com/doi/abs/10.1108/17260530810891306

Matlay, H. (2008). The impact of entrepreneurship education on entrepreneurial outcomes. Journal of Small Business and Enterprise Development, 15, 382-396. http://dx.doi.org/10.1108/14626000810871745

Mohd-Fauzi, M., Yahaya, I., Tih, S., \& Poon, J. (2007). Entrepreneurship \& Business Competitiveness. Fakulti Perniagaan dan Ekonomi, UKM Bangi, Bangi, Selangor. Retrieved from http://www.ukm.my/fep/index.php /about-us/staff/details/6/35/staff-directory-rozita-amiruddin?contentbuilder_download_file=917614a $8 \mathrm{a} 2 \mathrm{f} 88$ dc7016eb843d9905225c22b042a

Nawai, N., \& Shariff, M. N. M. (2011). The Importance of Micro Financing to the Microenterprises. Asian Social Science, 226-238. Retrieved from http://www.ccsenet.org/journal/index.php/ass/article/download/ $13438 / 9346$

Nkang, I. (2013). Re-Engineering Entrepreneurial Education For Employment and Poverty. Journal of Education and Practice, 4(2), 88-94. Retrieved from http://www.iiste.org/Journals/index.php/JEP/article/viewFile/ 4072/4107

Norfadhilah, N., \& Norasmah, O. (2012). Evaluation of Polytechnic Entrepreneurship Programs in Malaysia. International Journal of Trade, Economics and Finance, 3(5), 356-362. Retrieved from http://www.ijtef.org/papers/227-D00002.pdf

Normah, M. (2007). SMEs: Building blocks for economic growth. Paper presented at the National Statistical Conference. Kuala Lumpur. Retrieved from http://www.statistics.gov.my/portal/images/stories/files/journal/ smes.pdf

Oborah, J. (2006). Business Education and Entrepreneurial Development. A Surevey of Entrepreneurship opportunities. Business Education Journal, 34-38. Retrieved from http://infinitypress.info/index.php/jbae/ article/download/220/176

Ooi, K. Y. (2008). Inclination towards entrepreneurship among Malaysian university students in Northern Peninsular Malaysia. Retrieved February 24, 2014, from http://researchbank.swinburne.edu.au/vital/access/ manager/Repository/swin:8299

Othman, N., Hashim, N., \& Wahid, H. A. (2012). Readiness towards. Education $p$ Training, 697-708. Retrieved from http://library.oum.edu.my/oumlib/sites/default/files/file_attachments/odl-resources/4390/readiness.pdf

Othman, N., Othman, N. H., \& Ismail, R. (2012). Impact of Globalization on Trends in Entrepreneurship. International Journal of Trade, Economics and Finance, 3, 267-271. http://dx.doi.org/10.7763/IJTEF.2012.V3.212

Ramayah, T., \& Haron, Z. (2005). Entrepreneurial Intentions among University Sains Malaysia (USM) Students. International Journal of Management \& Entreprenuership, 21-29. Retrieved from http://scholar.google.com.my/scholar?q=related:Gnb4eKYvGm0J:scholar.google.com/\&hl=en\&as_sdt=0,5

Ramayah, T., Ahmad, N. H., \& Ho, T. (2012). Entrepreneurship Education: Does Prior Experience Matter? Journal of Entrepreneurship Education, 16, 65-75. Retrieved from http://www.freepatentsonline.com/article /Journal-Entrepreneurship-Education/289621051.html

Rosen, A. (2013, November 18). The Entrepreneurship Answer to Youth Unemployment. Retrieved April 2, 2014, from http://www.forbes.com/sites/amyrosen/2013/11/18/the-entrepreneurship-answer-to-youthunemployment/2/\#

Souitaris, V., Stefania, Z., \& Andreas, L. (2007). Do entrepreneurship programmes raise entrepreneurial intentions of science and engineering students? The effect of learning, inspiration and resources. Journal of Business Venturing, 22, 566-591. http://dx.doi.org/10.1016/j.jbusvent.2006.05.002

Weber, R., van Graevenitz, G., \& Harhoff, D. (2009). The Effects of Entrepreneurship. 2009 Max Planck Annual Summit Conference on Experimental Entrepreneurship. Retrieved from http://epub.ub.uni-muenchen.de/10966/3/EEE_WvGH_LMUe.pdf

Wennekers, S., \& Thurik, A. (1999). Linking entrepreneurship and economic growth. Small Business Economics, 27-55. http://dx.doi.org/10.1023/A:1008063200484

Wilson, K. (2008). Entrepreneurship Education in Europe. In ENTREPRENEURSHIP AND HIGHER EDUCATION (pp. 1-20). OECD. Retrieved from http://www.oecd.org/cfe/leed/youth_bp_finalt.pdf 
Xavier, S. R., Kelley, D., Kew, J., Herrington, M., \& Vorderwülbecke, A. (2012). GEM 2012 Global Report. Retrieved from http://www.gemconsortium.org/docs/download/2645

Yahya, U. (2011, February 9). WHY WE SET UP ENTREPRENEURSHIP STUDIES IN VARSITIES-FG. Retrieved March 25, 2014, from http://www.thenigerianvoice.com/nvnews/45849/1/why-we-set-upentrepreneurship-studies-in-varsities.html

\section{Copyrights}

Copyright for this article is retained by the author(s), with first publication rights granted to the journal.

This is an open-access article distributed under the terms and conditions of the Creative Commons Attribution license (http://creativecommons.org/licenses/by/3.0/). 